\title{
Damaging effects of water-borne cadmium chloride on DNA of lung cells of immature mice
}

\author{
X.F. Yang*, Y.M. Ge*, H.T. Zhang, H.M. Ning, J.Q. Jiang, Y.H. Qi and Z.L. Wang \\ College of Animal Science, Henan Institute of Science and Technology, \\ Xinxiang, China \\ *These authors contributed equally to this study. \\ Corresponding author: Z.L. Wang \\ E-mail: wangzl_2008@yahoo.com.cn \\ Genet. Mol. Res. 11 (4): 4323-4329 (2012) \\ Received February 14, 2012 \\ Accepted June 22, 2012 \\ Published September 25, 2012 \\ DOI http://dx.doi.org/10.4238/2012.September.25.2
}

\begin{abstract}
We investigated the effects of cadmium on lung cell DNA in immature mice. The mice were randomly divided into four groups: control group, low-dose group $\left(1 / 100 \mathrm{LD}_{50}\right)$, middle-dose group $\left(1 / 50 \mathrm{LD}_{50}\right)$, and high-dose group $\left(1 / 25 \mathrm{LD}_{50}\right)$; they were supplied with cadmium chloride or control water for 40 days. Lung cells collected from sacrificed mice were used to evaluate the extent of DNA damage by comet assay. The ratio of tailing cells, DNA tail length, DNA comet length, DNA tail moment, DNA olive tail moment, and percentage of DNA in the comet tail were measured. The rate of tailing lung cells exposed to cadmium increased significantly; the low-concentration group had significantly $(\mathrm{P}<0.05)$ higher rates, and the middle- and high-concentration groups had higher $(\mathrm{P}<0.01)$ rates compared to the control. DNA tail length, DNA comet length, DNA tail moment, and DNA olive tail moment all increased with the increase in cadmium doses, but compared with those of the control group, no significant differences in low-dose group were found ( $\mathrm{P}>0.05)$, and the differences in middleand high-dose groups were all highly significant $(\mathrm{P}<0.01)$. The degree of DNA damage also increased with the increase of the cadmium concentrations. We conclude that cadmium significantly increases DNA
\end{abstract}


damage in lung cells of immature mice in a dose-dependent manner.

Key words: Cadmium; DNA damage; Mice; Comet assay

\section{INTRODUCTION}

Cadmium is a ubiquitous environmental pollutant owing to its widespread use in industry throughout the world. It is a nonessential heavy metal with teratogenic, carcinogenic, and mutagenic effects as a pollutant (Burger, 2008). It can cause severe toxicity in various organs - mainly the kidney, liver, bone, lung, and genitals - which leads to urinary, digestive, skeletal, respiratory, and reproductive system dysfunction and human health hazards. Well-known itai-itai disease, which developed in Japan, is the most severe form of chronic cadmium poisoning and is caused by prolonged cadmium ingestion (Takaki et al., 2004). Consequently, the International Agency for Research on Cancer has classified cadmium as a group I human carcinogen (Godt et al., 2006).

Lung tissue is one of the main targets of cadmium toxicity (Oberdörster, 1992), and the respiratory system is affected severely by the inhalation of cadmium-contaminated air. Shortness of breath, lung edema, and destruction of mucous membranes as part of cadmium-induced pneumonitis have been described (Seidal et al., 1993). Cadmium causes lung damage, pulmonary fibrosis, emphysema, and inflammation in human and experimental animals. Cadmium may also adversely affect the lungs by decreasing the viability or modifying the function of individual lung cells (Lag et al., 2002). The toxic mechanisms responsible for cadmium-induced lung cell damage are not well understood. One study (Kostial et al., 1978) has suggested that immature mice might be more sensitive than mature mice or rats to toxic metals in the environment. However, little information is known about the toxic effects of cadmium on lung cells during periods of developmental growth or immaturity. The aim of the present study was to use the comet assay to evaluate the damaging effects of cadmium on lung cell DNA in immature mice.

\section{MATERIAL AND METHODS}

\section{Animals}

Twenty-four healthy Kunming mice (12 males and 12 females) weaned at $20 \pm 1$ days of age were obtained from the Centre for Laboratory Animal of Xinxiang Medical University (Xinxiang City, Henan, China). Animals were housed in groups under standard animal husbandry conditions (12-h light and 12-h dark) with ad libitum access to a standard commercial rodent diet.

\section{Cadmium administration}

After a 5-day acclimatization period, the mice were randomly divided into 4 groups: control, low dose $\left(1 / 100\right.$ median lethal dose $\left.\left[\mathrm{LD}_{50}\right]\right)$, middle dose $\left(1 / 50 \mathrm{LD}_{50}\right)$, and high dose $\left(1 / 25 \mathrm{LD}_{50}\right)$. Each group contained female and male mice. The $\mathrm{LD}_{50}$ for cadmium chloride is 187 $\mathrm{mg} / \mathrm{kg}$ body weight according to an acute toxicity test (Yang et al., 2012).

The various concentrations of cadmium chloride were dissolved in deionized water. The mice in the experimental group freely drank water containing cadmium chloride, whereas control mice had ad libitum access to deionized water. The total treatment time was 40 days. All procedures were approved by the local animal Ethics Committee. 


\section{Preparation of single-cell suspensions}

After treatments, the animals were killed via heart perfusion with normal saline. The lungs of each animal were removed, washed 3 times with phosphate-buffered saline (PBS), cut into pieces with eye scissors, homogenized with the appropriate amount of PBS in a glass homogenizer at $0^{\circ}$ to $4^{\circ} \mathrm{C}$, and filtered through a mesh. Single-cell suspensions remained in PBS at approximately $10^{6} / \mathrm{mL}$ for immediate comet assay.

\section{Comet assay}

Comet assays were performed according to guidelines proposed by Singh et al. (1988), with minor modification. Briefly, cells were suspended on $0.5 \%(\mathrm{w} / \mathrm{v})$ low-melting-point agarose, spread onto microscope slides precoated with $0.5 \%(\mathrm{w} / \mathrm{v})$ normal-melting-point agarose, and covered with a layer of low-melting-point agarose. The slides were then dipped into an ice-cold alkaline lysing solution $[2.5 \mathrm{M} \mathrm{NaCl}, 100 \mathrm{mM}$ disodium salt of ethylenediaminetetraacetic acid, 10 $\mathrm{mM}$ Tris, $1 \%(\mathrm{v} / \mathrm{v}) \mathrm{N}$-lauroyl sarcosine sodium salt, $10 \%$ dimethyl sulfoxide, and $1 \%(\mathrm{v} / \mathrm{v})$ Triton $\mathrm{X}-100, \mathrm{pH} 10]$ and placed in the dark for $1 \mathrm{~h}$ at $4^{\circ} \mathrm{C}$. After lysis, the slides were incubated for 20 min in a horizontal gel electrophoresis tank with alkaline electrophoresis buffer $(0.3 \mathrm{M} \mathrm{NaOH}$ and $1 \mathrm{mM}$ disodium salt of ethylenediaminetetraacetic acid, $\mathrm{pH} 13$ ) at $4^{\circ} \mathrm{C}$. Electrophoresis was carried out at $25 \mathrm{~V}, 300 \mathrm{~mA}$ for $20 \mathrm{~min}$. After electrophoresis, the slides were dried with filter paper, and neutralization buffer ( $0.4 \mathrm{M}$ Tris, $\mathrm{pH} 7.5$ ) was applied for $15 \mathrm{~min}$. The slides were then stained with $30 \mu \mathrm{g} / \mathrm{mL}$ ethidium bromide for at least $20 \mathrm{~min}$ and examined (original magnification 200X) using a fluorescence microscope (Nikon, Japan) with green light excitation and a 590-nm barrier filter.

Image analysis and quantification were performed using the Comet Assay Software Project (version 1.2.3; http://casplab.com/index.php). The ratio of tailing was assessed by counting the tailing DNA in 100 cells/animal. One hundred and fifty cells per group (6 slides of 25 cells/animal) were chosen randomly and photographed to measure comet parameters with the Comet Assay Software Project. The parameters were tail length (TL, pixels), comet length (CL, pixels), tail moment (TM, arbitrary units), and olive tail moment (OTM, arbitrary units). The cells were graded into 5 categories according to the percentage of DNA in the comet tail based on guidelines proposed by Prieto González et al. (2011). Comets with more than 50\% of the material in the tail and no detectable nuclei were classified as clouds and not scored (Collins, 2004).

\section{Statistical analysis}

The ratio of tailing among the various groups was compared using chi-square tests in SPSS 10.0 (SPSS Inc., Chicago, IL, USA). The data of TL, CL, TM, and OTM are reported as means \pm SEM and compared for significance using the Student $t$-test in SPSS 10.0. The value $\mathrm{P}<0.01$ was considered to be highly statistically significant.

\section{RESULTS}

Typical and clear comet images are shown in Figure 1. The migration of DNA (tailing DNA) was observed in cadmium-treated groups (Figure 1B, C and D), whereas no tailing DNA was evident in $93.5 \%$ of the cells analyzed in the control group (Figure 1A). As shown in Table 
1, the ratios of tailing lung cells exposed to various doses of cadmium increased significantly, and the difference was significant $(\mathrm{P}<0.05)$ between the control and the low-dose group and highly significant $(\mathrm{P}<0.01)$ between the control and the middle- and high-dose groups. The differences between every 2 treatment groups were all highly significant $(\mathrm{P}<0.01)$.
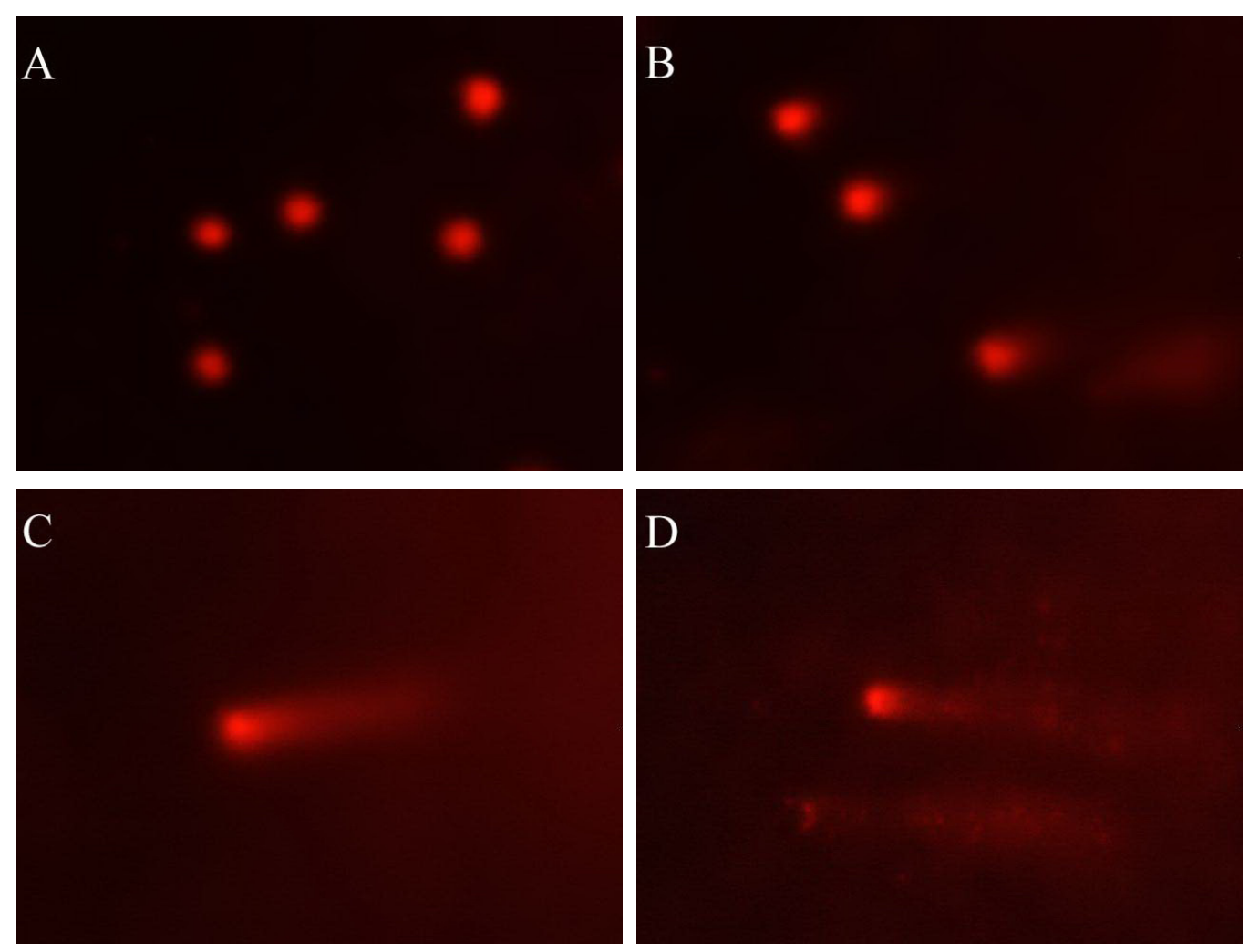

Figure 1. Typical photomicrographs of comet assay of immature mice lung cells. A. Comet of lung cells in the control group (grade 0 DNA damage, 200X); B. comet of lung cells in the low-dose group (grade 1 DNA damage, 200X); C. comet of lung cells in the middle-dose group (grade 3 DNA damage, 200X); D. comet of lung cells in the high-dose group (grade 4 DNA damage, 200X).

Table 1. Effects of cadmium on DNA damage of lung cells in immature mice.

\begin{tabular}{lccc}
\hline Groups & No. of mice & No. of cells analyzed & Ratio of tailing (\%) \\
\hline Control group & 6 & 600 & $6.5^{\mathrm{Aa}}$ \\
Low dose group & 6 & 600 & $10.0^{\mathrm{Ab}}$ \\
Middle dose group & 6 & 600 & $73.0^{\mathrm{Bc}}$ \\
High dose group & 6 & 600 & $91.7^{\mathrm{Cd}}$ \\
\hline
\end{tabular}

Different lower case superscript letters mean significant difference $(\mathrm{P}<0.05)$. Different capital superscript letters mean highly significant difference $(\mathrm{P}<0.01)$.

TL, CL, TM, and OTM are common parameters of DNA damage used to evaluate DNA damage. As shown in Table 2, TL, CL, TM, and OTM values increased in a dose-depen- 
dent manner with the increase of cadmium dose, but no significant differences were observed between the control and the low-dose group $(\mathrm{P}>0.05)$. Maximum values were found in the high-dose group and the differences of each of these values compared with those of the control group were highly significant $(\mathrm{P}<0.01)$. The differences between every 2 treatment groups were significant $(\mathrm{P}<0.05)$ or highly significant $(\mathrm{P}<0.01)$.

Table 2. Effects of cadmium on comet parameters of tailing lung cells in immature mice.

\begin{tabular}{lccrrr}
\hline Groups & No. of cells analyzed & TL & CL & TM & OTM \\
\hline Control group & 150 & $23.40 \pm 5.85^{\mathrm{Aa}}$ & $76.80 \pm 4.35^{\mathrm{Aa}}$ & $4.88 \pm 2.08^{\mathrm{Aa}}$ & $3.50 \pm 1.05^{\mathrm{Aa}}$ \\
Low dose group & 150 & $36.94 \pm 6.46^{\mathrm{ABa}}$ & $87.32 \pm 7.03^{\mathrm{Aa}}$ & $8.42 \pm 2.63^{\mathrm{Aa}}$ & $6.67 \pm 1.59^{\mathrm{ABa}}$ \\
Middle dose group & 150 & $57.14 \pm 5.24^{\mathrm{Bb}}$ & $125.70 \pm 5.22^{\mathrm{Bb}}$ & $23.19 \pm 3.90^{\mathrm{Bb}}$ & $11.52 \pm 1.55^{\mathrm{Bb}}$ \\
High dose group & 150 & $126.14 \pm 6.82^{\mathrm{Cc}}$ & $187.24 \pm 7.00^{\mathrm{Cc}}$ & $64.33 \pm 5.51^{\mathrm{Cc}}$ & $36.66 \pm 3.20^{\mathrm{Cc}}$ \\
\hline
\end{tabular}

Same superscript letters mean no statistical difference ( $\mathrm{P}>0.05)$; different lower case superscript letters mean significant difference $(\mathrm{P}<0.05)$; different capital superscript letters mean highly significant difference $(\mathrm{P}<0.01)$. $\mathrm{TL}=$ tail length; $\mathrm{CL}=$ comet length; $\mathrm{TM}=$ tail moment; $\mathrm{OTM}=$ olive tail moment.

The extent of damage can be expressed by measuring the percent of DNA present in the tail in the comet assay. The percentages of damaged cells are shown in Figure 2. The degree of DNA damage in the control and low-dose groups did not reach grades 3 or 4; DNA damage at grades 0 and 1 comprised 96 and 2\%, respectively, of the control and corresponded to 88 and $8 \%$, respectively, in the low-dose group. The grade 3 damage in the middle- and high-dose groups reached 11.3 and $48 \%$, respectively, but the damage at grade 4 was 0 and $3.3 \%$, respectively.

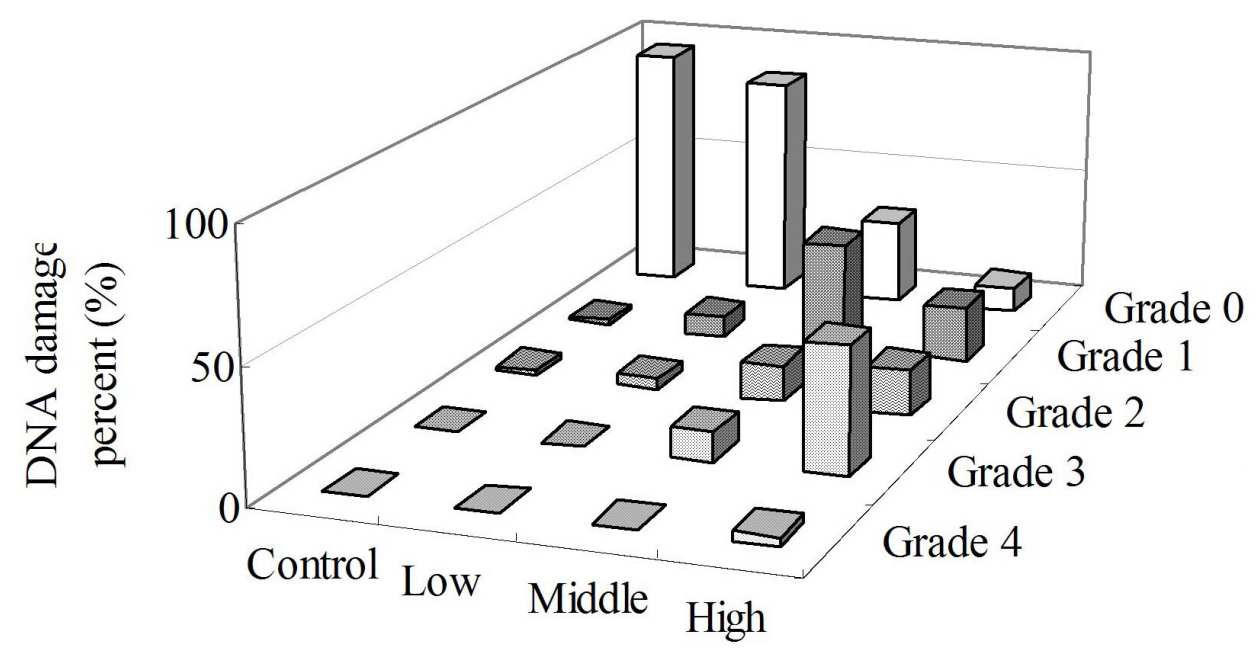

\section{Group}

\section{$\square$ Grade $4 \quad \square$ Grade $3 \quad \square$ Grade $2 \quad \square$ Grade $1 \quad \square$ Grade 0}

Figure 2. Histogram of undamaged and migrated lung cells in control, low-, middle- and high-dose groups. 


\section{DISCUSSION}

Route of exposure is an important determinant of the genotoxicity of a chemical owing to its mode of action (Sekihashi et al., 2002). The amount of cadmium absorbed by the body depends on the route of entry. Approximately 5-6\% of a given dosage of cadmium is absorbed from the gastrointestinal tract, whereas lung absorption is as high as $90 \%$ of an inhaled dose. In non-occupational-exposure populations and nonsmokers, oral intake is a major route of cadmium entry into the body. Our study established animal models that consumed cadmium-containing water, which is consistent with the route of natural human cadmium exposure.

Immature humans may be more susceptible than adults to the toxicity of cadmium after cadmium enters the body. Most previous studies have used mature animals to research cadmium toxicity, but the intoxication effect of cadmium in immature animals was poor. To investigate the effect of cadmium exposure on lung cell DNA damage in immature mice, we used weaning mice as model animals, in which a 40-day cadmium exposure period encompassed the entire growth and development period of the animals. The results showed that cadmium induced lung cell DNA damage in immature mice when the dose reached and exceeded $1 / 100 \mathrm{LD}_{50}$. DNA damage increased considerably with increases in the concentration of administered cadmium in a dose-dependent fashion.

The importance of analyzing DNA damage as a biomarker of effects in humans exposed to metals was confirmed. In this regard, DNA damage, which is induced by a variety of metals, could be used as a biomarker at polluted sites (Calderón et al., 2003). The lung is a target organ for cadmium toxicity (Lag et al., 2002). Kundu et al. (2009) have found that low cadmium exposure $(5 \mathrm{mg} / \mathrm{kg}$ body weight) in Swiss albino mice causes no significant DNA damage, whereas exposure to $80 \mathrm{mg} / \mathrm{kg}$ body weight of intraperitoneal cadmium induces comet tail formation. In the present study, although the differences in TL, CL, TM, and OTM in the lung cells of mice in the low-dose group was not significant $(\mathrm{P}>0.05)$ compared with that in the control group, these parameter values were obviously higher than those of the control, and the tailing rate differed significant $(\mathrm{P}<0.05)$. The percentage of cell damage that reached grades 1 and 2 in the low-dose group increased by 4 and 2 times, respectively, compared with that in controls. Our data indicated that the lung cells of immature mice lung were affected adversely when mice were exposed to very low doses of cadmium after weaning, which is not consistent with a report by Kundu et al. (2009). We considered two main reasons for this effect: 1) lung cells of immature animals are more sensitive than those of adult animals to cadmium exposure, and 2) cadmium is a heavy metal with a low excretion rate, which results in extremely long biological half-lives in animals and humans. A 40-day exposure period provided enough time for cadmium to accumulate in various tissues and organs, including the lung. Other reasons may be different dosage, route and time. Our results suggested that the administration of cadmium was associated with lung cell DNA damage in immature mice in a dose-dependent fashion and might affect the respiratory system of these animals.

The formation of 8-hydroxy-2'-deoxyguanosine $(8-\mathrm{OHdG})$ is regarded as an important marker of DNA damage. Yu (2000) has found that cadmium can generate 8-OHdG as a basemodified product. 8-OHdG is capable of pairing with any base, causing base pair mismatches and inducing mutation and cancer. Mikhailova et al. (1997) have found that cadmium at low concentrations of 5-35 $\mu \mathrm{M}$ induces the formation of $8-\mathrm{OHdG}$ and causes nuclear DNA strand breaks. Cadmium has been reported as a weak mutagen by Pei et al. (2003), who concluded that direct or indirect effects in DNA might induce DNA damage, and this damage is mainly single- or double- 
stranded DNA damage, DNA-protein cross-links, and DNA repair inhibition. Potts et al. (2001) have indicated that cadmium can interfere with antioxidative functions in alveolar epithelial cells, injuring cell DNA and inhibiting DNA damage repair. Our present study suggested that cadmium induces lung cell DNA damage in immature mice even at a low dose. It may be an important mechanism of cadmium-induced lung toxicity that requires further study in immature mice.

To the best our knowledge, this preliminary study is the first to demonstrate the effects of cadmium on lung cell DNA damage in immature mice. Lung cell DNA strands are adversely affected when weaned mice are exposed even to low doses of cadmium for 40 days. The rate and degree of lung cell DNA damage increased with increasing cadmium dose in a dose-dependent manner. Therefore, our data suggest that cadmium ingestion is associated with lung cell DNA damage in immature mice and may be an early biomarker of cadmium toxicity in these animals.

\section{ACKNOWLEDGMENTS}

Research supported in part by grants from the Aid Project for the Leading Young Teachers in Henan Provincial Institutions of Higher Education of China (\#2010GGJS-136).

\section{REFERENCES}

Burger J (2008). Assessment and management of risk to wildlife from cadmium. Sci. Total Environ. 389: 37-45.

Calderón J, Ortiz-Pérez D, Yáñez L and Díaz-Barriga F (2003). Human exposure to metals. Pathways of exposure, biomarkers of effect, and host factors. Ecotoxicol. Environ. Saf 56: 93-103.

Collins AR (2004). The comet assay for DNA damage repair. Mol. Biotechnol. 26: 249-261.

Godt J, Scheidig F, Grosse-Siestrup C, Esche V, et al. (2006). The toxicity of cadmium and resulting hazards for human health. J. Occup. Med. Toxicol. 1: 22.

Kostial K, Kello D, Jugo S, Rabar I, et al. (1978). Influence of age on metal metabolism and toxicity. Environ. Health Perspect. 25: 81-86.

Kundu S, Sengupta S, Chatterjee S, Mitra S, et al. (2009). Cadmium induces lung inflammation independent of lung cell proliferation: a molecular approach. J. Inflamm. 6: 19.

Lag M, Westly S, Lerstad T, Bjornsrud C, et al. (2002). Cadmium-induced apoptosis of primary epithelial lung cells: involvement of Bax and p53, but not of oxidative stress. Cell Biol. Toxicol. 18: 29-42.

Mikhailova MV, Littlefield NA, Hass BS, Poirier LA, et al. (1997). Cadmium-induced 8-hydroxydeoxyguanosine formation, DNA strand breaks and antioxidant enzyme activities in lymphoblastoid cells. Cancer Lett. 115: 141-148.

Oberdörster G (1992). Pulmonary deposition, clearance and effects of inhaled soluble and insoluble cadmium compounds. IARC Sci. Publ. 189-204.

Pei XC and Xu ZF (2003). Chronic toxicity and remote effect of cadmium. Chin. J. Environ. Occup. Med. 20: 58-61.

Potts RJ, Bespalov IA, Wallace SS, Melamede RJ, et al. (2001). Inhibition of oxidative DNA repair in cadmium-adapted alveolar epithelial cells and the potential involvement of metallothionein. Toxicology 161: 25-38.

Prieto González EA, Ortega Soler M, Fuchs AG, Brito R, et al. (2011). Differences in DNA repair kinetics of lesions induced by hydrogen peroxide in lymphocytes from premenopausal breast cancer patients and healthy Women resident in Great Buenos Aires. J. Med. Med. Sci. 2: 1036-1046.

Seidal K, Jorgensen N, Elinder CG, Sjogren B, et al. (1993). Fatal cadmium-induced pneumonitis. Scand. J. Work Environ. Health 19: 429-431.

Sekihashi K, Yamamoto A, Matsumura Y, Ueno S, et al. (2002). Comparative investigation of multiple organs of mice and rats in the comet assay. Mutat. Res. 517: 53-75.

Singh NP, McCoy MT, Tice RR and Schneider EL (1988). A simple technique for quantitation of low levels of DNA damage in individual cells. Exp. Cell Res. 175: 184-191.

Takaki A, Jimi S, Segawa M, Hisano S, et al. (2004). Long-term cadmium exposure accelerates age-related mitochondrial changes in renal epithelial cells. Toxicology 203: 145-154.

Yang XF, Ge YM, Jiang JQ, Xu ZY, et al. (2012). Acute toxic effect of cadmium chloride in mice. Chin. J. Vet. Sci. 32: 467-471. Yu RA (2000). Cadmium and DNA damage, oncogene expression as well as cell apoptosis. Overseas Med. Health 27: 359-363. 